Ramadani L., Rashiti N., Bekolli L., Heta G. Influence of some anthropometric, motor and bone mass parameters on short distance running. Journal of Education, Health and Sport. 2021;11(12):47-55. eISSN 2391-8306. DOI http://dx.doi.org/10.12775/JEHS.2021.11.12.004 https://apcz.umk.pl/JEHS/article/view/JEHS.2021.11.12.004

https://zenodo.org/record/5759686

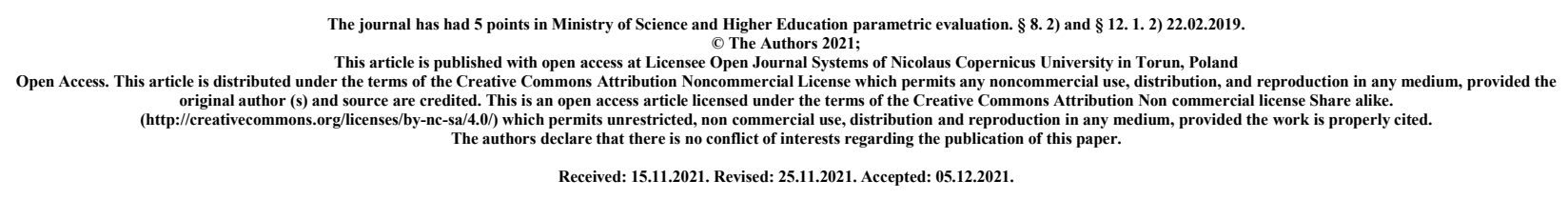

\title{
Influence of some anthropometric, motor and bone mass parameters on short distance running
}

\author{
Ramadani L. ${ }^{1}$, Rashiti N. ${ }^{1}$, Bekolli L. ${ }^{1}$, Heta G. ${ }^{2}$ \\ University of Prishtina, Faculty of Physical Education and Sport, Prishtina, Kosova
}

\begin{abstract}
The knowledge on morphological development and their impact on motor skills in short distance athletes should be one of the main preoccupations of athletics coaches, because any scientific research in the field of physical culture and sports is concerned with proving the development and evaluation of anthropological characteristics which are responsible in achieving success in athletics. The purpose of this paper is to prove the impact of some anthropometric, motor-specific characteristics and those of bone weight in short distance running, specifically in 100 meters, with students aged $19 \pm 6$ years, of the Faculty of Physical Education and Sports in Pristina. The sample of this research included a total of 75 students aged 19 of the Faculty of Physical Education and Sports in Pristina. The variables which were applied in this research were 7 anthropometric variables and 6 motor variables and 1 specific motor variable. Regression analysis in the manifest space was applied to determine the relationship between predictive variables (anthropometric and motor characteristics) and criterion variable (100 m running).
\end{abstract}

Keywords: anthropometry, motor, bone mass, 100 m running, regression.

\section{INTRODUCTION}

Athletics operates on the basis of a certain system of practical knowledge and practical skills, which has in its content the theoretical and methodological bases of teaching and sports training [1]. Athletic operates on the basis of a particular system of knowledge that has in its content the theoretical and methodological foundations of sport training [2]. Running is the most universal tool for the athlete's all-round training, but it also occupies an extremely important place in the training of other types of sports.

During running, the body receives many demands on the work of the muscular system and vasocardial and respiratory activity. It is an important tool for maintaining and strengthening 
health. Athletic running, as a set of physical movements of a cyclical character, realizes the displacement in space and time through the steps with the lower sides (legs) at a greater speed than in race walking. $[3,4,6]$.

Speed running is a natural form of movement display in general and athletics in particular. These types constitute one of the basic tools of comprehensive preparation: physical, functional and psychological. [6] This is the main reason why they are constantly valued, especially in the context of exercising as a goal for sporting achievement.

Climatic conditions play a role in the outcome of the runs. The breath or wind, depending on the direction in which it blows, can increase or decrease the athlete's speed. Atmospheric pressure or air pressure can be taken into account, but it has no effect because the run is too short and the amount of oxygen for this distance is mostly concentrated in the runners muscles. [7].

An athlete may not have swollen and developed muscles, but he is taller and has the biggest stride. In the length of the athlete a distinction must be made between the stature in general and the length of the legs and the throwing of the step. [9]. Within this, statistical tests and interpretation of results were performed in separate subheadings. After the interpretation of the results, an explanation was given for the importance of the study from the theoretical and practical point of view, also in a separate subheading.

\section{PURPOSE OF RESEARCH}

Like any transversal research that aims to prove the relationships, influence, dependence between different anthropological characteristics, abilities and states, this research is based on proving the influence of one anthropological field with another in order to increase information for the benefit of identification of factors that are of particular importance in enhancing the motor skills of the anaerobic character.

The purpose of this paper is to prove the impact of some anthropometric characteristics, bone mass, motor-specific, on the speed of execution of short distance runs, specifically in 100 meter runs on 19-year-old students.

\section{SAMPLE OF VARIABLES}

\section{Variables for estimating morphological characteristics:}

Body Height (ALATR), Body Mass (APETR), Muscle Mass (AAMUS), Bone Mass (APSHK), Body Mass Index (IMT), Leg Length (AGJKEM), Arm Length (AGJDOR).

\section{Variables for evaluating basic motor skills:}

Running 30 meters (V30M), Standing Long jump (MKGJAT), Standing High Jump (MKLAR), Standing High Jump with the Right Foot (MKDJA), Standing High Jump with the Left Foot (MKMAJ), Throwing of Med Ball Lying Down (MHMED).

Specific motor variables: Running 100 m High Start (KV100M) 


\section{METHODS OF PROCESSING THE RESULTS}

\section{Basic central and distribution parameters:}

Arithmetic mean (Am), Standard deviation (Sd), Minimum value (MinV), Maximum value (MaxV), Coefficient of variation (Cv).

2. The distribution curve is tested by the asymmetry coefficient ("Skewness"), and the degree of curvature of the vertex of the distributed results curve (distribution height) through the flat coefficient ("Kurtosis").

3. Reports of the interrelationships between variables in the manifest space, as well as correlations between the system of variables.

4. To determine the relationship between predictor variables (anthropometric characteristics, bone and motor weight) and the criterion variable (running $100 \mathrm{~m}$ ) regression analysis was applied in the manifest space.

DESCRIPTIVE ANALYSIS OF ANTHROPOMETRIC VARIABLES, BONE MASS BASIC AND SPECIFICIFIC MOTOR

Table 1 presents the descriptive analysis of anthropometric variables - specific motor bone mass in 19-year-old students of the Faculty of Physical Education and Sports.

The sample included the group of 75 male students, where the values of arithmetic mean, minimum score, maximum score, standard deviation, distribution or parameters of asymmetry (Skewness - tilt, asymmetry) and the degree of extension of the curve vertex are presented in the distribution of results ( Kurtosis - convexity), and Coefficient of variation (Cv).

Table 1. Basic statistical parameters of anthropometric, basic and specific motor variables of 19-year-old students of the Faculty of Physical Education and Sports

\begin{tabular}{|l|c|r|r|r|r|r|r|c|}
\hline Tab.1 & $\mathrm{N}$ & Minimum & Maximum & Mean & $\begin{array}{c}\text { Std. } \\
\text { Deviation }\end{array}$ & Skewness & Kurtosis & Kv \\
\hline ALATR & 75 & 165.5 & 197.6 & 178.691 & 6.14304 & 0.706 & 1.387 & 3.44 \\
\hline APETR & 75 & 54.6 & 87.8 & 71.1093 & 7.45948 & 0.034 & -0.15 & 10.49 \\
\hline AAMUS & 75 & 46.5 & 73.8 & 57.7419 & 5.74172 & 0.137 & -0.122 & 9.94 \\
\hline APSHK & 75 & 2.5 & 3.8 & 3.0564 & 0.25048 & 0.316 & 0.381 & 8.2 \\
\hline IMT & 75 & 17.11 & 27.68 & 22.3524 & 2.14534 & 0.073 & 0.084 & 9.6 \\
\hline AGJKEM & 75 & 90 & 110 & 99.6907 & 4.65204 & -0.071 & -0.086 & 4.67 \\
\hline AGJDOR & 75 & 74.3 & 88.7 & 80.352 & 2.88343 & 0.599 & 0.906 & 3.59 \\
\hline V30M & 75 & 4.25 & 4.71 & 4.3908 & 0.1186 & 0.41 & -0.96 & 2.7 \\
\hline MKGJAT & 75 & 1.9 & 2.8 & 2.3533 & 0.19579 & -0.117 & -0.377 & 8.32 \\
\hline MKLAR & 75 & 29.2 & 47 & 37.1733 & 4.17419 & 0.278 & -0.489 & 11.23 \\
\hline MKDJA & 75 & 13.7 & 25.7 & 19.2707 & 2.60212 & 0.513 & 0.064 & 13.5 \\
\hline MKMAJ & 75 & 14.3 & 29.4 & 20.252 & 3.82726 & 0.55 & -0.452 & 18.9 \\
\hline MHMED & 75 & 6.15 & 9.5 & 7.7253 & 0.77505 & 0.624 & -0.683 & 10.03 \\
\hline KV100M & 75 & 8.7 & 14.1 & 11.7208 & 1.14831 & -0.48 & 0.481 & 9.8 \\
\hline
\end{tabular}




\section{Photo 1. Histogram of anthropometric variable - body height (ALATR)}

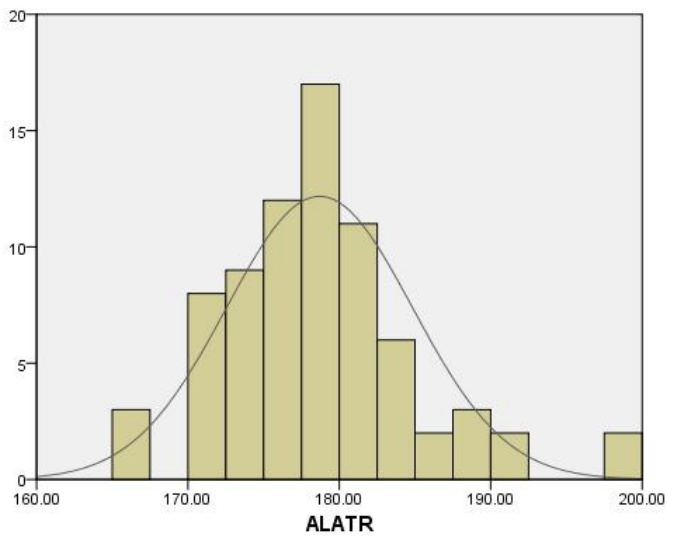

pronounced asymmetry.
Arithmetic mean of anthropometric variable

Body height (BH) is $178.69 \mathrm{~cm}$. The lowest $165.50 \mathrm{~cm})$ and the highest results $(197.69 \mathrm{~cm})$ of the variable Body height indicates that there is a marked difference between students in this motor variable, as well as a slight inclination of the variable towards higher results, because the asymmetry test is negative (platykurtic). Students in this anthropometric variable are presented as a homogeneous group $(\mathrm{Kv}=3.4 \%)$ with a larger number of values towards the higher ones. The pronounced difference between the highest and lowest result indicates that the acquired flexibility and convexity (Skewness and Kurtosis) do not have a

\section{INTERCORRELATION MATRIX}

\section{Intercorelation matrix of anthropometric variables, motor and specific motor}

The intercorrelation matrix of anthropometric variables is presented in Table 2. Thus the statistically significant coefficients of the variables with the highest degree of statistical inference $(p<0.01)$ are denoted by two asterisks. Easier statistical conclusion criterion $(p<0.05)$ correlation coefficients are marked with an asterisk. The correlation coefficients show that the variables are categorized into the following groups:

Table 2. Intercorrelation coefficients of anthropometric variables, motor and specific motor

\begin{tabular}{|c|c|c|c|c|c|c|c|c|c|c|c|c|c|c|}
\hline Tab. 2 & TRU & PTRU & MMUS & APKOC & IMT & AGJKE & AGJKRA & MV30M & IKGJVE & MKLAR & MKMAJ & MKDJA & MHMED & KV100M \\
\hline TRII & 1 & $60^{\circ}$ & (120** & $233^{\text {t1 }}$ & -0.17 & $802^{* t}$ & $988^{*+1}$ & 0.04 & 0.004 & 0.001 & 0.085 & 0.12 & 0.048 & 048 \\
\hline rinu & & 1 & .190 & & .710 & $.4 U \angle$ & & & & 0.092 & 0.196 & -0.094 & -0.049 & 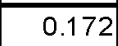 \\
\hline AMMUS & & $.790^{*}$ & 1 & $.651^{* *}$ & $.594^{* *}$ & $.254^{\star}$ & .386 & -0.116 & 0.047 & 0.015 & 0.121 & -0.064 & 0.063 & 0.06 \\
\hline APKOC & & $.579^{*}$ & $.651^{\star \prime \prime}$ & 1 & $.391^{n}$ & $.274^{*}$ & $.293^{*}$ & -0.11 & 0.086 & 0.047 & 0.072 & 0.08 & 0.014 & 0.04 \\
\hline AIMT & -0.174 & $.778^{\star}$ & $504^{\star *}$ & $91^{\star *}$ & 1 & -0.194 & -0.167 & -0.055 & 0.033 & 0.068 & 0.13 & -0.209 & -0.095 & \\
\hline AGJKE & $.802^{*+}$ & $.402^{*}$ & & & -0.19 & 1 & $.800^{*}$ & & & 0.047 & 0.157 & 0.133 & 0.074 & \\
\hline AGJKRA & $.988^{*}$ & $56^{*}$ & .386 & $.293^{\circ}$ & -0.17 & $.800^{*+1}$ & 1 & 0.054 & -0.002 & 0.05 & 0.098 & 0.128 & 0.068 & 0.02 \\
\hline MV30M & 0.04 & -0.019 & -0.116 & -0.11 & -0.06 & 0.054 & 0.054 & 1 & $-.754^{\text {*t }}$ & $-.266^{*}$ & -0.047 & $-.336^{* 1}$ & -0.192 & -0.21 \\
\hline MKGJVE & 0.004 & 0.036 & 0.047 & 0.086 & 0.033 & -0.059 & -0.002 & $-.754^{\star}$ & 1 & $.328^{*}$ & 0.159 & $.364^{* *}$ & 0.116 & .333 \\
\hline MKLAR & -0.001 & 0.092 & 0.015 & 0.047 & 0.068 & 0.047 & 0.05 & $-.266^{*}$ & $.328^{*}$ & & $.508^{* x}$ & $.598^{* x}$ & 0.092 & 0.17 \\
\hline MKMAJ & 0.085 & 0.196 & 0.121 & 0.072 & 0.13 & 0.157 & 0.098 & -0.047 & 0.159 & $.508^{* 1}$ & 1 & $.575^{* *}$ & 0.124 & $\overline{0.2}$ \\
\hline MKDJA & 0.12 & -0.094 & -0.064 & 0.08 & -0.21 & 0.133 & 0.128 & $-.336^{\star}$ & $.364^{* x}$ & $.598^{*}$ & $.575^{\star *}$ & & 0.146 & 0.07 \\
\hline MHMED & 0.048 & -0.049 & 0.063 & 0.014 & -0.1 & 0.074 & 0.068 & -0.192 & 0.116 & 0.092 & 0.124 & 0.146 & & 0.0 \\
\hline $\mathrm{KV} 100 \mathrm{M}$ & 0.046 & 0.172 & 0.067 & 0.045 & 0.156 & 0.136 & 0.026 & -0.217 & $.333^{\text {*t }}$ & 0.172 & 0.21 & 0.073 & 0.09 & \\
\hline
\end{tabular}

In the group (anthropometric) in terms of the height of the correlation coefficients are the anthropometric variables that belong to the longitudinal dimension and that the correlation 
coefficients are brought from the highest correlation value $.899 * *$ to the lowest $.333 * * \mathrm{p}<0.0$. The second group in terms of the height of the correlation coefficients consists of anthropometric variables that belong to the dimensions of body mass and volume as well as subcutaneous adipose tissue and that the correlation coefficients brought from the highest correlation value .293

* to the lowest $.254^{*}, \mathrm{p}<0.05$.

In the (motor) group, the height of the correlation coefficients consists of the motor variables that belong to the motor dimension of the explosive force of the lower extremities and that the correlation coefficients are brought from the highest correlation value $.754 * *$ to the lowest .336 $*^{*}, \mathrm{p}<0.01$. The second group in terms of the height of the correlation coefficients consists of the motor variables that belong to the motor dimension of the explosive force of the upper extremities and that the correlation coefficients brought about the high correlation value $.328 *$ to the lowest $-.266^{*}, \mathrm{p}<0.05$.

In the first group (specific motor) in terms of the height of the correlation coefficients are the specific motor variables that belong to the specific motor dimension of running $30 \mathrm{~m}$ and $100 \mathrm{~m}$ and that the correlation coefficients are brought from the highest correlation value $.333 *, p<$ 0.01 . 
Table 3. Regression analysis - correlation and influence of anthropometric and motor parameters as independent (predictor) variables on the dependent variable (criterion) Running 100 meters from low start (LSR100m.)

\begin{tabular}{|l|r|r|r|r|}
\hline Model & R & R Square & $\begin{array}{c}\text { Adjusted R } \\
\text { Square }\end{array}$ & $\begin{array}{c}\text { Std. Error of the } \\
\text { Estimate }\end{array}$ \\
\hline 1 & $.557^{\mathrm{a}}$ & .311 & .112 & 1.05052 \\
\hline
\end{tabular}

a. Predictors: (Constant), MHMED, APKOC, MKLAR, AGJKE, MV30M, AIMT, MKMAJ, MKGJVE, MKDJA, AMMUS, AGJKRA, ALTRU, APTRU

ANOVA $^{\mathrm{a}}$

\begin{tabular}{|rl|r|r|r|r|l|}
\hline Model & & Sum of Squares & \multicolumn{1}{c|}{ df } & Mean Square & F & Sig. \\
\hline \multirow{3}{*}{1} & Regression & 22.391 & 13 & 1.722 & 1.561 & $.133^{\mathrm{b}}$ \\
& Residual & 49.661 & 45 & 1.104 & & \\
& Total & 72.052 & 58 & & & \\
\hline
\end{tabular}

a. Dependent Variable: KV100M

b. Predictors: (Constant), MHMED, APKOC, MKLAR, AGJKE, MV30M, AIMT, MKMAJ, MKGJVE, MKDJA, AMMUS, AGJKRA, ALTRU, APTRU

Coefficients $^{\mathrm{a}}$

\begin{tabular}{|l|r|r|r|r|r|}
\hline \multirow{2}{*}{ Model } & \multicolumn{2}{|c|}{ Unstandardized Coefficients } & \multicolumn{2}{c|}{$\begin{array}{c}\text { Standardized } \\
\text { Coefficients }\end{array}$} & \multicolumn{1}{c|}{ Sig. } \\
\cline { 2 - 5 } & \multicolumn{1}{|c|}{ B } & Std. Error & Beta & \\
\hline \multirow{2}{*}{ (Constant) } & -56.750 & 41.565 & & -1.365 & .179 \\
& .589 & .279 & 3.215 & 2.116 & .040 \\
ALTRU & -.339 & .283 & -2.251 & -1.197 & .238 \\
APTRU & -.040 & .043 & -.233 & -.943 & .351 \\
AMMUS & -.305 & .554 & -.097 & -.552 & .584 \\
APKOC & 1.247 & .902 & 2.339 & 1.383 & .174 \\
AIMT & .120 & .063 & .503 & 1.925 & .061 \\
AGJKE & -.780 & .391 & -1.997 & -1.991 & .053 \\
AGJKRA & 1.073 & 1.919 & .117 & .559 & .579 \\
MV30M & 2.445 & 1.147 & .430 & 2.131 & .039 \\
MKGJVE & .052 & .050 & .188 & 1.041 & .303 \\
MKLAR & .061 & .078 & .139 & .787 & .436 \\
MKMAJ & -.067 & .062 & -.216 & -1.083 & .285 \\
MKDJA & .154 & .204 & .103 & .756 & .453 \\
\hline
\end{tabular}

a. Dependent Variable: KV100M

Through regression analysis in students, the correlation between the group of independent predictor variables (basic anthropometric and motor variables) and the dependent criterion variable - Running 100 meters from the low start (LSR100m.) was confirmed. Regression analysis in students shows that the value of the correlation between the group of independent predictor variables (basic anthropometric and motor variables) and the dependent criterion variable - Running 100 meters from the low start (LSR100m.) has been confirmed. Connectivity of the whole system of independent predictor variables (basic anthropometric and motor variables): Body height (BH), Body mass (BM), Muscle mass (MM), Bone mass (BM), body mass index (BMI), Leg length (LL), Arm length (AL), Running 30 meters (R30m.), Standing Long jump (SLJ), Standing High jump (SHJ), Standing High jump with the right foot (SHJRF), Standing High jump with the Left foot (SHJLF), Throwing of Med ball (THMB), has been 
proven by multiple correlation. The multiple correlation coefficient has the value $\mathrm{R}=.557$ which explains the common variability between the system of predictor variables and the criterion variable about $31 \%(\mathrm{R}$ Square $=0.311)$.

The distribution (F) is obtained as the quotient distribution of the two variances, and in these cases it is always necessary to assign the two degrees of freedom. The first degree of freedom is equal to the number of predictor variables $(\mathrm{df}=\mathrm{n})$ respectively $(\mathrm{df}=14)$ while the second is performed so that the number of subjects reduced by the number of predictive variables minus 1 $(\mathrm{df}=\mathrm{N}-\mathrm{n}-1)$ respectively $(\mathrm{df}=50-14-1)$. We can emphasize that the test (F-test) is always more valuable if the multiple correlation is greater, in the concrete case of this paper is significant $(\mathrm{Sig}=.133)$, because the value of the F-test is 1.561 .

\section{CONCLUSION}

In addition to longitudinal anthropometric parameters, special importance is given to motor skills, especially those of explosive force, which occupies an important place in athletics.

High peak results can only be achieved during a long and well-organized training process, which is subject to the laws of bio-psycho-social development as well as possible training stimulus and necessary for the dynamic development of basic and specific motor and anthropometric skills.

In this paper (research) the population from which the sample was selected for research for this paper is defined as the population of students (males) of late adolescence.

The sample of this research included a total of 75 students aged $19 \pm 6$ years of the Faculty of Physical Education and Sports Pristina.

For both groups of the system of variables the basic statistical and distribution parameters for each variable are calculated, as well as the asymmetry measures and the normal distribution of the correlation ratio and regression analysis.

The results obtained from the collection of information and their processing show that:

a) Some of the anthropometric features have had pronounced asymmetry indicating that the sample has been heterogeneous in terms of morphological development.

b) Some of the specific speed-motor skills have had pronounced asymmetry indicating that the sample has been heterogeneous with different results.

c) The results obtained from the regression analysis show that in the dependent variable or Running 100 meters from low start (MV100MU) the anthropometric variable Body height (ALART) has an impact, Beta $=3.215$ which is not confirmed by the probability scale, Sig $=.133$.

We can conclude that from short-distance running 100 meters, to medium-distance running and long-distance running the influence of anthropometric parameters decreases and the influence of metabolic factors of energy production increases. 


\section{REFERENCES}

[1]. Rashiti, N. Ibri, L. Pireva, A. Shala, S. Maliqi, A. "Analysis of differences of some anthropometric and motor variables with high school students of different age inovaciji $\mathrm{V}$ obrezovanieto" Shumen, Bulgaria, 2010.

[2]. Rashiti, N. Elezi, A. Maliqi, A. (2020)10 "Impact of some motor abilities on the manifestation of endurance with highschool students at the age 16 years" Nacionalnata sportna akademija "V. Levski" broji 1(10)2010 Sofi.

[3]. Myrtaj, N. Rashiti, N. Shkodra, M. Elezi, I.(2010) "Influence of the different kinesiologys treatments in development of some motor abilities of youth ruse" Bulgaria, ISSN 1311-3321.

[4]. Maliqi A., Ramabaja Q., Ramadani L., Latifi B. The impact of some morphological characteristics on running 200 meters. Journal of Education, Health and Sport. 2021;11(6):52-59. eISSN 2391-8306. DOI http://dx.doi.org/10.12775/JEHS.2021.11.06.007.

[5]. Ramabaja Q., Rashiti N., Shkodra M., Ramadani L. The impact of some morphological and motor characteristics in short distance running. Journal of Education, Health and Sport. 2021;11(6):109-119. eISSN 2391-8306.

[6]. Maliqi, A. Rashiti, N. Nura, A. Myrtaj, N. (2010) "Vrednost psihomotorickih sposobnosti i antropometriskih varjabla na relaciju kratkih distance zbornike naucnih i strucnih radova sporta $\mathrm{i}$ zdravlje" Tuzla Issm 1840-4790.

[7]. Čoh, M. (2003). Razvoj brzine u kondicijskoj pripremi sportaša. U D. Milanović i . Jukić (Izd.), Međunarodni znanstveno-stručni skup Kondicijska priprema sportaša (str. 229-234). Zagreb: Kineziološki fakultet Sveučilišta u Zagrebu, Zagrebački Športski Savez.

[8]. Rashiti, N. (2011). Prediktivna vrjednost baterije motorocki testova kod tercanje na kratke i srednje staze, "Sport Mont", br. 25-27, str. 260- 265.

[9]. Radiḱ, Z. A.Simeonov (2006), Relacije izmeŕu morfoloshkih karakteristika i rezultata u skoku u daљ, FIS Komunikacije, Nish.

[10].Radiḱ, Z, A.Simeonov (2006), Vlijanie na motorichki varijabli vrz rezultatot vo skok vo dalechina vo atletski pettoboj, Mezhdunarodna konferencija po Leka Atletika, Sofija.

[11]. Bogen,M.,\&O.Fatissov(2001).Riddlesofthe100msprint.TrackCoach,155, 4960-4961.

[12]. Ramadani, L. Heta, G. Bekolli, L. Rashiti, N. Ramabaja, Q. Millaku, A. "The impact of short run distances to the final results of the decathlon at the 2019 Athletic World Championships" Journal of Education, Health and Sport. 2019;9(12):101-109. eISSN 2391-8306. 2020 . 
[13]. Rashiti, N. Ramabaja, Q. Bekolli, L. Gontarev, S. Ramadani, L. "The impact of some morphological and motor characteristics in short distance running" Pedagogy and Psychology of Sport. 2021;7(2):106-113. elSSN 2450-6605.

[14].Mikić, B. (2000). Osnovi psihomotorike. Tuzla: Fakultet sporta i tjelesnog odgoja.

[15].Nikitjuk, B. A. (1986). Genetika i somatotip u sportu. Kineziologija Vol. 18, br. 1.

[16].Opavski, P. (1971). Osnovi biomehanike. Beograd. „Naučna knjiga“.

[17].Pržulj, D. (2005). Osnovi antropomotorike. Istočno Sarajevo: Fakultet fizičke kulture.

[18]. Pavlović, R. (2010). Atletika. Istočno Sarajevo: Fakultet fizičkog vaspitanja i sporta.

[19]. Myrtaj, N. Rashiti, N. Shkodra, M. Elezi, I.(2010) "Influence of the different kinesiologys treatments in development of some motor abilities of youth ruse" Bulgaria, ISSN 1311-3321.

[20]. Heta, G. Bekolli, L. Ramadani, L. Ramabaja, Q. Rashiti, N.(2020) "Difference between midfield and forward football players in active and passive Body Mass Index as well as in the aerobic capacity" Open Access ISSN 2391-8306 formerly ISSN: 1429-9623 / 2300- 665X, 2020.

[21]. Šnajder, V. (1988). Atletika - Znanstvene osnove. Zagreb: Fakultet za fizičku kulturu sveučilišta u Zagrebu.

[22]. Šnajder, V. (1994). Uticaj specifičnih i bazičnih motoričkih varijabli na rezultate sprinta kod učenica. Kineziologija Vol 26, br. 1-2, str.

[23]. Tončev, I. (1983).Uticaj programirane ciklične aktivnosti na aerobnu sposobnost omladinaca, Doktorska disertacija. Novi sad: Fakultet fizičke kulture.

[24]. Tončev, I. (2001). Atletika-tehnika i obučavanje. Novi Sad: Fakultet fizičke kulture. 